\title{
Current status of the invasive pest (Tuta absoluta) and other pest complex on tomato crop in Karnataka
}

\author{
S. Aparna ${ }^{1}$, A. R. V. Kumar ${ }^{2}$ \\ ${ }^{1}$ Ph.D. scholar, of Agricultural Entomology, UAS, GKVK, Bengaluru, 560065 \\ ${ }^{2}$ Rtd. Professor, Department of Agricultural Entomology, UAS, GKVK, Bengaluru, 560065
}

\begin{abstract}
Tomato is one of the commercially important vegetable crops in India. Recently, an invasive pest Tuta absoluta was introduced to India causing potential yield loss to the tomato crop. Several studies were undertaken on the pest since 2014 to understand the biology, distribution, host range, natural enemies and chemical management of the pest. It is important to understand the current status of the pest at regular time intervals to validate the existing practices and to development suitable management technologies. Thus, current study aims at understanding the spatial variation in the pest incidence in randomly sampled 24 tomato fields in larger tomato growing areas viz., Chikkaballapur and Kolar of southern parts of Karnataka from August to December, 2018. There was no recognizable pattern in spatial distribution of the pest damage on the crop vegetation and the fruit yield. Intensity of pest incidence on different plant canopies as well as fruit yield were observed to be very low to low ( 0 - 20 per cent) in 70 per cent of the sampled locations. Subsequently, less than 10 per cent of locations showed high pest infestation. Further, in all the locations, 10-22 per cent of yield loss was observed to be due to insect pest, diseases and/or nutritional deficiency in the sampled locations. In the total loss incurred, about 50 percent of the damage caused by the incidence of Tuta absoluta alone. Further studies have to be conducted on the effect of biotic and non-biotic factors on the pest population, effect of prevailing management practices on the natural enemies to understand the current status of the pest in different seasons.
\end{abstract}

KEYWORDS: American pinworm, Tomato pest, Insect pest complex, Tuta absoluta

\section{INTRODUCTION}

Tomato originated in the woods of Peru as a wild plant, until 16th century native South American people did not use because of misconception as toxic plant. It was introduced to India by Portugal explorers in 16th century. Now, it is most popular vegetable in the world and India stands in 3rd position for area (8.8 lakh ha) under cultivation [1].

In past 25 years, this plant was infested by several pests, at least 3 (out of 10) invasive pests viz., the American serpentine leafminer, Liriomyza trifolii, Bemesia tabaci biotype B and Tuta absoluta. Such introduced pests exploit the environment for breeding and establishment in the absence of natural enemies [2]. It was first reported from the state Maharashtra in India causing leaf and fruit damage was from 0.5 to 60 per cent in different locations [3]. Within two years after its first report (October 2014) it has spread to north and other southern parts of India. The exact routes of spread within India are very difficult to predict. The possible reasons could be the unsupervised movement of agricultural commodities across the states or countries and this was also enhanced by heavy wind currents. [4]. Plants are damaged by the larvae that feed on leaves, stems, buds, calyces, young fruit, or ripe fruit causes yield loss. Further, the invasion of secondary pathogens through the wounds made by the pest lead to low marketable yield.

In India, several studies were undertaken on the pest since 2014 to understand the biology, distribution, host range, natural enemies and chemical management of the pest. The pest has spread to most of the tomato growing throughout the India despite constant efforts made by several government institutions to contain the pest spread. It is important to undertake studies on its biology, distribution, host range, natural enemies and their conservation. Development of an efficient IPM program calls for a good understanding of the crop-pest system and hinges on the various knowledge and technology bases. However, foremost of that understanding the current status of the pest is essential part of the development of suitable management practices. In this context, this study aims at understanding the current status of pest incidence in the larger tomato growing area of southern parts of Karnataka.

\section{MATERIAL AND METHODS}

Survey was conducted to understand the status of the pest incidence under various farming practices in highest tomato growing area (i.e. Kolar) of southern part of Karnataka from 2018 August to December, 2019. Additionally, stage of the crop, level insect incidence on vegetation, and the various practices that farmer has already imposed for the containment of the target pest was 


\section{International Journal of Current Science Research and Review}

ISSN: 2581-8341

Volume 03 Issue 11 November 2020

DOI: 10.47191/ijcsrr/V3-i11-04, Impact Factor: 6.595

IJCSRR@ 2020

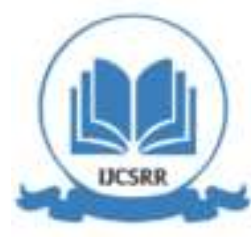

www.ijcsrr.org

recorded. The suitable questionnaire was developed for the purpose as also a data sheet to record the field situation of the pest status. About 25 farms were randomly selected from tomato growing areas of southern districts of Kolar.

In addition, Tuta absoluta and other insects were collected from the vegetation of sampling unit. All collected samples brought to the lab with suitable labels and documented for their potential role in the biology of T. absoluta. Ten randomly selected plants from each farm were sampled to quantify the pest incidence. Intensity of pest incidence on the vegetation was evaluated by counting damaged leaves out of 20 randomly selected leaves from upper, middle, and lower canopy of each plant. Further, total tomato yield from sampling units were divided into unmarketable and marketable fruits. Subsequently, unmarketable fruits were separated and recorded based on the damage caused by different pests, diseases and/or nutritional deficiency. The spatial variation in the pest intensity on vegetation and fruits in sampled areas were graphed using the Q-GIS.3.6 (www.qgis.org/en/site/)[5] software.

\section{RESULTS}

\subsection{Spatial distribution of the pest, $T$. absoluta damage on the tomato crop vegetation}

Leaf damage by the pest in different parts of the survey locations are represented here (Fig. 1.) Each circle in the map indicates the location of samples collected during survey. Different colors in each circle represent average of percent leaf damage observed in different plant canopy (Fig.1). Distribution map represents that pest incidence on vegetation has random distribution pattern.

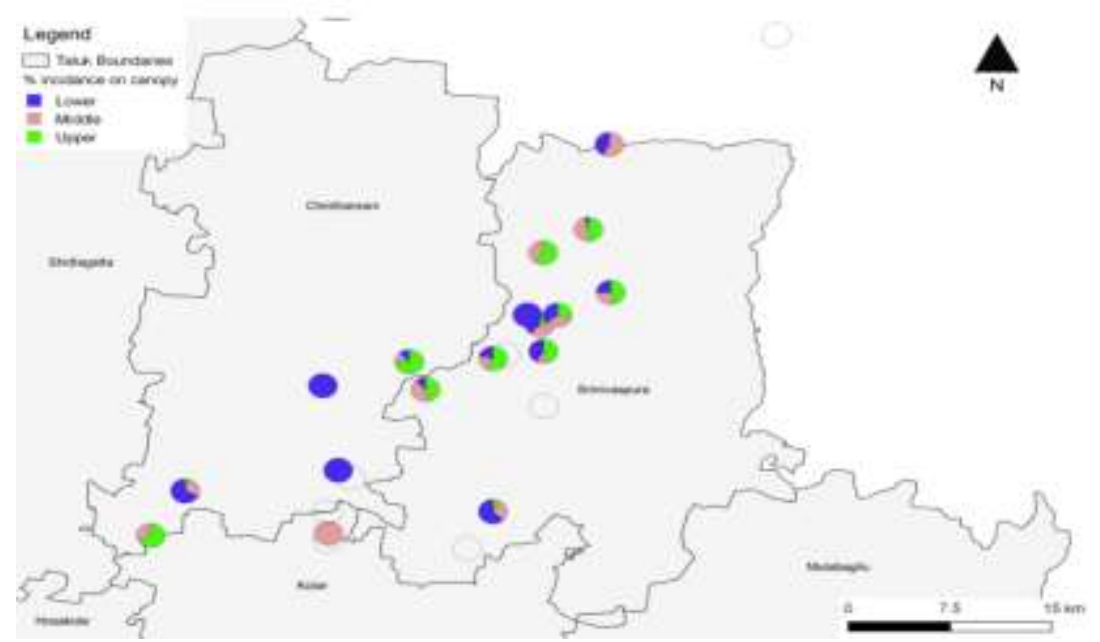

Fig. 1 Map representing the intensity of pest damage on vegetation in selected locations of Kolar and Chikkaballapur districts

\subsection{Proportional distribution of pest incidence in different crop canopy}

Intensity of pest incidence on the plant vegetation in sampled locations indicated that in all the canopies at least about 50 percent of the locations showed very low pest incidence. Only 40 per cent of the locations had moderated pest incidence in all the canopies (Fig.2).

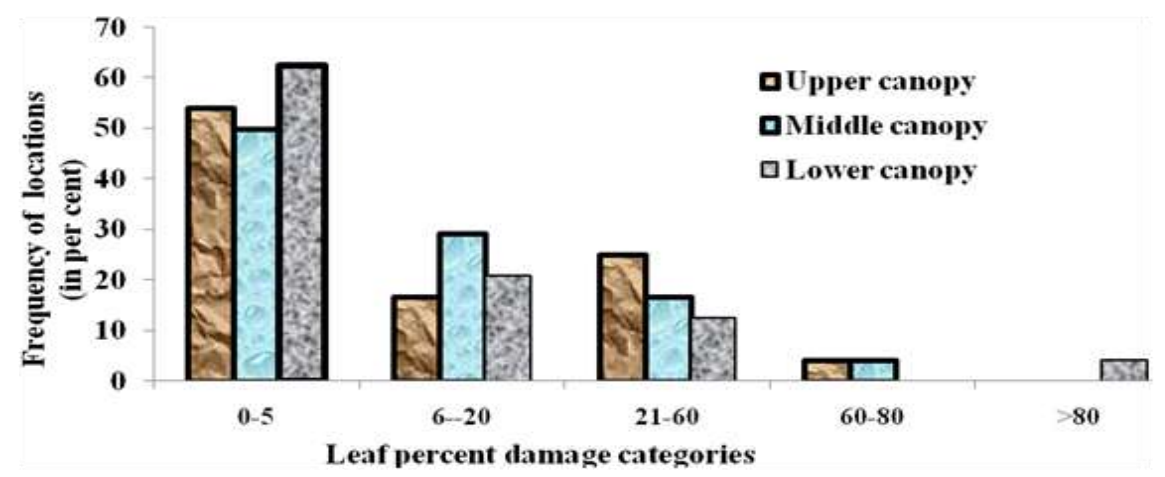

Fig. 2: Plant canopy wise frequency distribution of pest incidence in different sampled locations of Kolar and Chikkaballapur districts 


\section{International Journal of Current Science Research and Review}

ISSN: 2581-8341

Volume 03 Issue 11 November 2020

DOI: 10.47191/ijcsrr/V3-i11-04, Impact Factor: 6.595

IJCSRR@ 2020

www.ijcsrr.org

\subsection{Spatial distribution of the pest, $T$. absoluta damage on the tomato yield}

Fruit damage in different survey locations was indicated in Fig. 3. Different colored circles indicate the different intensity of damage (denoted as percent damage categories) in the sampled locations. About 60 percent of the locations were infested with very low intensity of fruit damage. About 30 percent of the locations had moderated pest incidence (Fig.4).

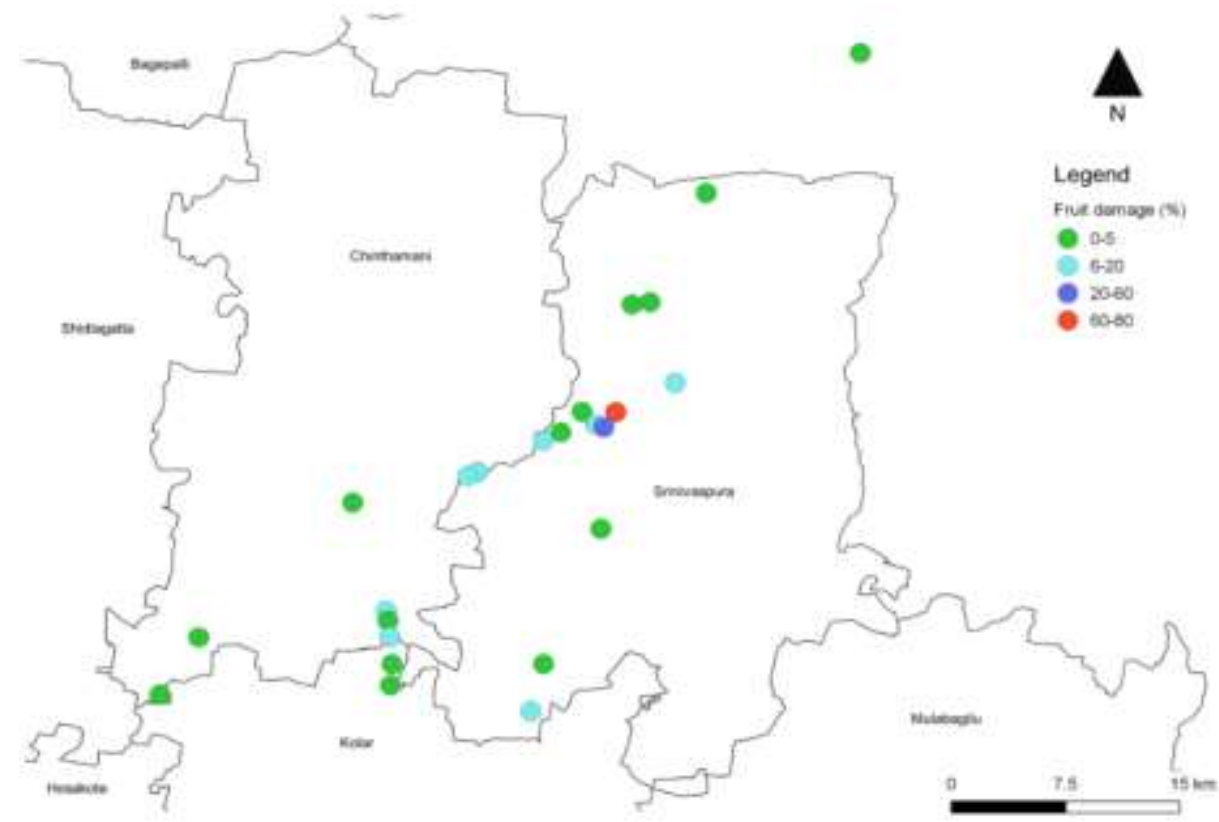

Fig 3. Map representing the intensity of pest damage on fruits in selected locations of Kolar and Chikkaballapur districts.

Different color indicates categories of percent fruit damage

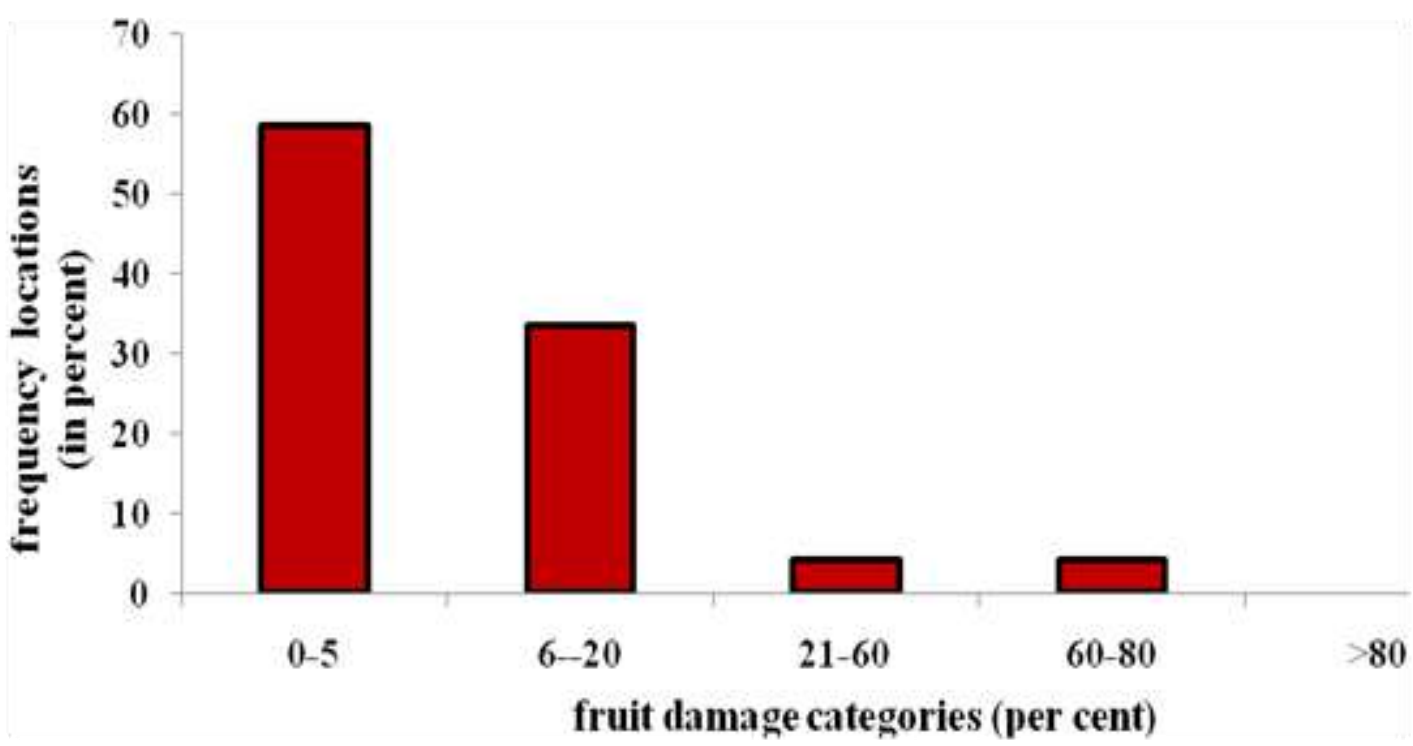

Fig. 4: Frequency distribution of fruit damage in different sampled locations of Kolar and Chikkaballapur districts

\subsection{Yield loss due to biotic and nutritional deficiency in tomato crop}

About 10-22 per cent of the yield loss was observed due to insect pest, diseases and/or nutritional deficiency in the sampled locations. In the total loss incurred, about $50 \%$ of the damage caused by the incidence of Tuta absoluta alone and followed calcium deficiency (22\%) and Helicoverpa armigera incidence (15\%) (Fig. 5). 


\section{International Journal of Current Science Research and Review}

ISSN: 2581-8341

Volume 03 Issue 11 November 2020

DOI: 10.47191/ijcsrr/V3-i11-04, Impact Factor: 6.595

IJCSRR@ 2020

www.jicsrr.org

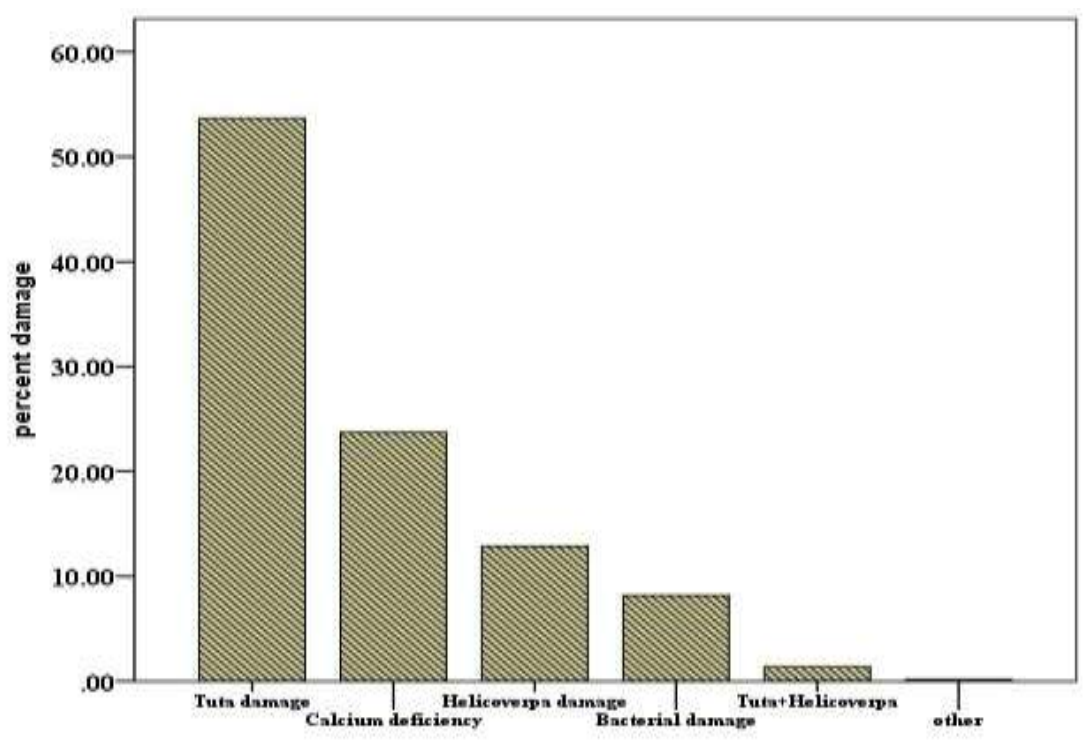

Fig.5: Proportional distribution of the yield loss due to insect pests, diseases and calcium deficiency in tomato crop in surveyed locations of Kolar and Chikkabalapur districts of Karnataka

\section{DISCUSSION}

The pest incidence in the largest tomato growing area of southern parts of Karnataka was evaluated in this study and it was observed to be very low in at least 70 per cent of the locations surveyed from August to December of the year 2018. Several conventional chemicals have been tested to control the pest in the recent 4 years. In India, an indiscriminate use of the pesticides like insecticides such as spinosad, chlorantranilyprole, abamectin, indoxacarb, delthamethrin, cypermethrin, was observed in the farmers field [6,7]. Further, Successful parasitisation by species of Genera Trichogramma, Gonizus, Neochrysocharis, Habrobracon observed on the different stages of the life cycle of the T. absoluta in India by NBAIR [8].

Due to the efforts and involvement of the ICAR intuitions, SAU's officials in creating awareness regarding the of pest and availability of suitable management practices, at the right time among the farmer and pesticide dealers might have helped to kept the pest under control. However, further studies have to be conducted on the effect of biotic and non-biotic factors on the pest population, effect of prevailing management practices on the natural enemies to understand the current status of the pest in different seasons [9].

\section{BIBLIOGRAPHY}

1. NHB (National Horticulture Board), 2014, (http://nhb.gov.in/default.aspx.) Accessed on 03/11/2018.

2. Desneux N, Wajnberg E, Wyckhuys KA, Burgio G, Arpaia S, Narváez-Vasquez CA, et al. Biological invasion of European tomato crops by Tuta absoluta: Ecology, geographic expansion and prospects for biological control. Journal of pest science. 2010;83(3):197-215.

3. Shashank PR, Chandrashekar K, Meshram NM, Sreedevi K. Occurrence of Tuta absoluta (Lepidoptera: Gelechiidae) an invasive pest from India. Indian Journal of Entomology. 2015;77(4):323

4. Shashank, P. R., Sachin, S. S., Chandrashekar, K., Naresh, M. And Kalleshwaraswamy, C. M., 2016, Rapid action plan for South American tomato pinworm: An invasive pest. ICAR NEWS, 22 (2): 24-25.

5. Q-GIS 3.6 software, 2019, (https://www.qgis.org/en/site/)

6. Silva GA, Picanço MC, Bacci L, Crespo AL, Rosado JF, Guedes RN. Control failure likelihood and spatial dependence of insecticide resistance in the tomato pinworm, Tuta absoluta. Pest management science. 2011;67(8):913-20.

7. Roditakis E, Skarmoutsou C, Staurakaki M. Toxicity of insecticides to populations of tomato borer Tuta absoluta (Meyrick) from Greece. Pest Management Science. 2013;69(7):834-40. 


\section{International Journal of Current Science Research and Review}

ISSN: 2581-8341

Volume 03 Issue 11 November 2020

DOI: 10.47191/ijesrr/V3-i11-04, Impact Factor: 6.595

IJCSRR@ 2020

www.ijcsrr.org

8. Ballal, CR, Ankita G, Mohan, M, Lalitha Y and Verghese A. The new invasive pest Tuta absoluta (Meyrick) (Lepidoptera: Gelechiidae) in India and its natural enemies along with evaluation of Trichogrammatids for its biological control. Current Science. 2016; 110(11):2155-2159.

9. Derbalah AS, Morsey SZ, El-Samahy M. Some recent approaches to control Tuta absoluta in tomato under greenhouse conditions. African Entomology. 2012; 20(1):27-34.

Cite this Article: S. Aparna and A. R. V. Kumar (2020). Current status of the invasive pest (Tuta absoluta) and other pest complex on tomato crop in Karnataka. International Journal of Current Science Research and Review, 3(11), $113-118$ 